\title{
Improving Project Change Management Using Leadership Spirit
}

\author{
Hamid Shafaei Bejestani \\ Board Director, P. M. Baranoosh Co., Mashad, Iran. \\ Email: hamshabej@yahoo.com \\ Received June $18^{\text {th }}$, 2011; revised July 23 ${ }^{\text {rd }}, 2011$; accepted August $10^{\text {th }}, 2011$.
}

\begin{abstract}
Projects seldom run exactly according to their plans due to changes. However, project deliverables must be provided on-time and on-budget, either by rejecting changes or by converting their threats to opportunities. To achieve this, project team should be kept ready to control changes. In this issue, leadership is an effective spirit for a project manager to keep his/her project team in its best condition for rejecting changes, or getting back on track, or earning benefits from changes. A project leader is more successful than a project manager in change management.
\end{abstract}

Keywords: Leadership, Change

\section{Introduction}

Management is partly science and partly art. It is also the same for project management and a project manager should know some arts as well as knowledge. These arts (soft skills) could be named as "Competencies” Managers who stand out as competent leaders share a certain set of characteristics. These characteristics are "personal skills" which are formed according to the responsibility of project managers. Because human resources are the greatest projects' assets, the skills related to them are important to leaders.

One the most important challenges for project manager are changes. These changes may be introduced to projects' scope and can produce acceptable or unacceptable effects on project deliverables. There are many methods and techniques in standard documents to control changes as "Change Management". However, these knowledge and methods would be performed by project team members and they are frontiers to control changes.

Author believes that the leadership characteristics of a project manager can affect change management directly and effectively because these characteristics facilitate interaction and support cooperation between project manager and his/her team members. Actually, a project leader is able to convert the natural possible resistances of team members to a synergetic and constructive interaction when the project is exposed to a change.

\section{Research Objectives}

This paper was prepared based on the results from many years experience in different projects as engineer, supervisor, manager, or consultant. Environmental, domestic and managerial conditions, changes occurred and problems resulted in these projects encouraged researcher to find a solution. In this issue, following question was introduced:

"Can a project manager with leadership characteristics increase his abilities to manage team members to control change resistances effectively?”

Hence, the theme of this research was determined as "Evaluating the role of leadership characteristics on the project change management”.

\section{Methodology}

Getting scientific goals is possible through a suitable methodology. On the other word, a research is valid by its methodology not its title. To have a suitable method, researcher needs to proceed according to a flowchart. First, two variables were determined. The independent variable of the research was selected as "Set of leadership characteristics" and the dependent variable to be evaluated was "Success of change management". Accordingly, a theoretical frame like a simple flowchart for research was made as shown in Figure 1. This frame has two stages and each stage has two sub-stages as follows: 


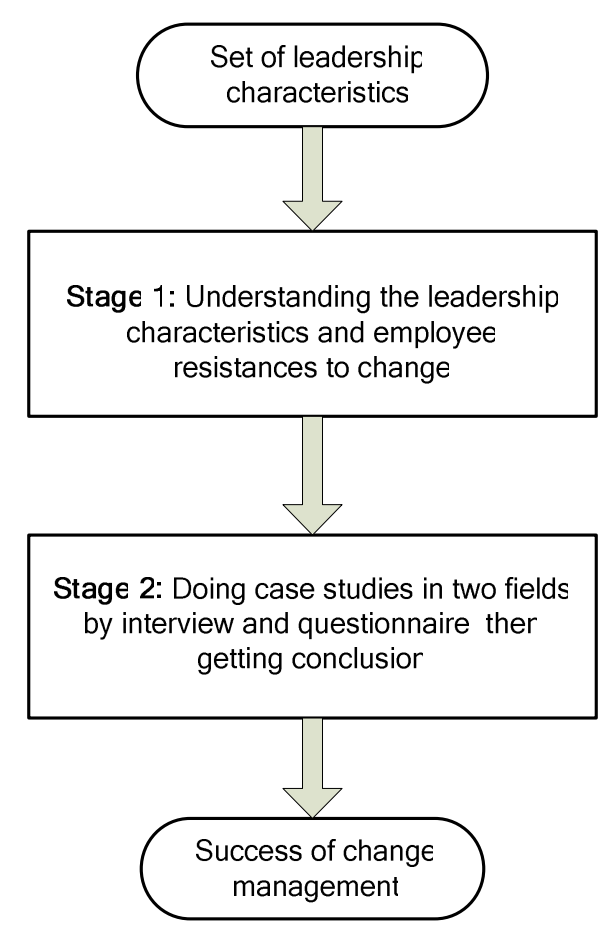

Figure 1. Theoretical frame of research.

\section{Stage 1}

1-1. Understanding leadership characteristics;

1-2. Understanding employee resistances to change;

Stage 2

2-1. Case studies;

2-2. Conclusion;

Following, these sub-stages are discussed.

\subsection{Leadership Characteristics}

In this sub-stage, the main characteristics of a leader will be described. First, some questions should be answered. Who is a leader? And what is the leadership?

Lao Tzu, an Imperial librarian and writer in ancient China, believes that a leader is a catalyst. It means that a leader can facilitate works and induce others to work toward some predetermined objectives. The superior leader gets things done with very little motion. He imparts instruction not through many words but through a few deeds. Leadership is the power of persuading people to do what they don't want to do, or do what they are too lazy to do, and like it.

There are many characteristics which are introduced as leadership personal skills in many manuscripts. In relation with this research, these characteristics are consistency, observation, problem solving, training friendly, humor, communication and responsibility. They can be defined as simple as shown in Table 1. Author believes that these characteristics could be useful to manage a project to which is exposed a change.
Table 1. Definitions of some leadership charactristic.

\begin{tabular}{|c|c|}
\hline Characteristic & Definition \\
\hline Consistency & $\begin{array}{l}\text { To build confidence in the people who work } \\
\text { for you }\end{array}$ \\
\hline Observation & $\begin{array}{l}\text { To observe team members \& their behaviors } \\
\text { (e.g. reaction under different conditions) }\end{array}$ \\
\hline Problem solving & $\begin{array}{l}\text { To make right decision \& solve problems, } \\
\text { specially under critical conditions }\end{array}$ \\
\hline Training friendly & To believe on training necessity \& benefits \\
\hline Humor & $\begin{array}{l}\text { To build a happiness space without non- } \\
\text { logical stress }\end{array}$ \\
\hline Communication & To have face-to-face relation \\
\hline Responsibility & To be responsible to get objectives \\
\hline
\end{tabular}

\subsection{Employee Resistances to Change}

What is the change in a project? Generally, a change is the process of intentionally moving from one defined state to another [1]. In a project, for example, you are going to build a steel bridge, but investors decide to use concrete because of the increasing price of steel. As another example, suppose that it is planned to use robots in a production line, but the new policy of government for decreasing the unemployment rates forces you to use manual-based technology. These are some examples and we should keep in mind that change may happen all of the time. So a project manager should have some skills and strategies for handling changes.

Change management plays a key role in the success of a project. It describes a structured approach to transitions from the present state to a desired state. It includes the process, tools and techniques to manage people-side of change [2]. Change management can help us to get benefits such as: Increase in the implementation success rates, developing the employee performance, reducing time-todo, reduction of resistance to change and so on. Related to this, it will be shown that reducing resistance to change and developing the employee performance could be achieved effectively by leadership spirit. In the other word, a project leader can control the employee resistances of change better than a project manager. Any change leads to stress and discomfort. These conditions are reasons to resist change [3]. Actually, employees have some reasons for resist to change and it will be reflected in their behavior. These reflections produce negative results which will affect on the project performance. This process is shown in Figure 2.

The reasons of employee resistance are not simply changeable. Also, after obtaining the negative results of such reflections, it is difficult to remove or reduce their 


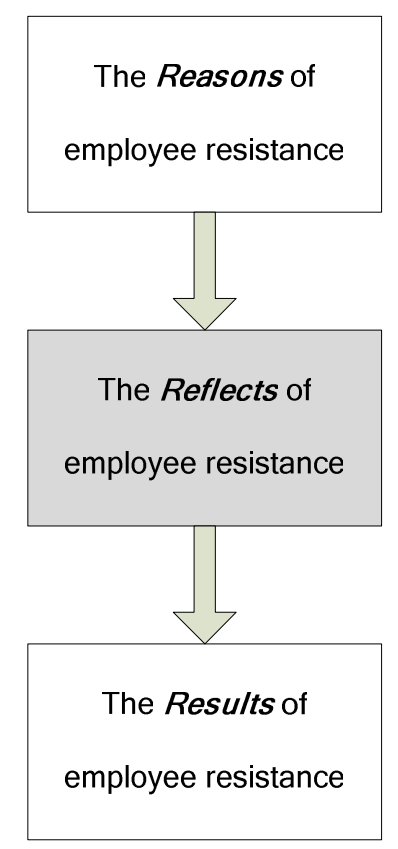

Figure 2. Reasons, reflects and results of employee resistance to change.

effects. But it is possible to reduce negative reflects by improving the leadership characteristics of a project manager.

Hence, it would be beneficial to focus on the reflections of employee resistance. Some of these reflections could be as follows:

1) Lack of self-reliance

2) No success anxiety

3) Worry about job position

4) Worry about revenue reduction

5) Worry about added work

6) Distrust between team members

These items have negative influences on employees such as decreasing motivation, reducing teamwork interest, increasing conflicts, and so on. All of these effects are capable to decrease projects' performance while we would like to improve it during changes. On the other side, leadership characteristics can remove or reduce these negative influences. As an example, humor makes a fresh workshop and in such a place, there is no space for any anxiety or worry. In addition, humor helps to increase trust between team members.

\subsection{Case Study}

Leadership characteristics, employee resistances to change, and its reflections were discussed above. To find the answer of main question, a tabular questionnaire was designed as shown on Appendix. Then, this questionnaire was distributed among the members of supervisory teams of two different projects (one industrial and one construction). It is necessary to note that the sampling society was small and a meeting was arranged with them to introduce the research items, but not objectives.

It must be noted that workers get salary to do a specified job or an activity. Generally, they do not care about changes. If they should perform an activity again, no problem, they will be paid again! But there is a difference with supervisors. Normally, a supervisor who prefers to work in a project-oriented organization would not like routine or repeatable activities. For instance, a project planner likes to plan different projects, not different versions of a plan. Therefore, questionnaire papers were distributed among supervisors. Also, they are familiar with management processes as well as challenges.

\subsection{Results}

Using statistical average calculation, A table was generated as shown in Figure 3. According to this table, row averages in this case studies show that the highest effect of leadership is on No success anxiety and second one is Lack of self-reliance. If you have self-reliance, not only you have no anxiety, but also you work better to get success. The next priorities are Distrust epidemic and Worry about job position. If there is any distrust in a team, they will be worry about threats of their workmates. Finally, the low priorities indicate less influence on Worry about added work and Worry about revenue loss. On the other side, column averages and their priorities indicate some considerable results. Humor and Communication have highest priorities and effects. So, project managers should think about them, because it is not difficult and expensive to make a happy workplace and to communicate with team members!

The total average is about \%40. It means a considerable effect of leadership characteristics on decreasing employee resistances to change and reflections. Therefore, a project manager who has leadership characteristics can increase his/her abilities to manage team members to control change resistances effectively. This means his success to change management. Generally, these characteristics are categorized as leadership competencies.

\section{Conclusions}

According to the results, it presents that leadership spirit have considerable effects on reducing employee resistances to change and developing success of change management. In the other word, a project leader can improve the projects' performance during a change. In conclusion, it is recommendable to include leadership training in the project management courses. The name of this course may be such as "Leadership competency". It 


\begin{tabular}{|c|c|c|c|c|c|c|c|c|c|c|}
\hline & & \multicolumn{7}{|c|}{ Leadership characteristics } & \multirow[b]{2}{*}{ 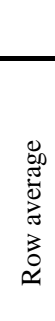 } & \multirow[b]{2}{*}{ 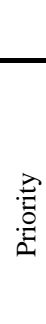 } \\
\hline & & 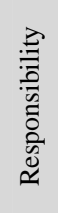 & 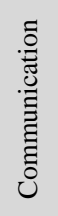 & 兽 & 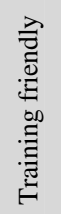 & 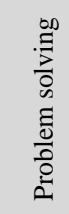 & 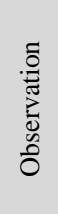 & 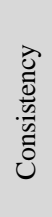 & & \\
\hline \multirow{6}{*}{ 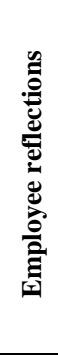 } & Lack of self-reliance & 36 & 70 & 74 & 44 & 39 & 41 & 66 & 53 & 2 \\
\hline & No success anxiety & 54 & 56 & 67 & 43 & 78 & 27 & 75 & 57 & 1 \\
\hline & Worry about job position & 30 & 56 & 53 & 17 & 30 & 56 & 23 & 38 & 4 \\
\hline & Worry about revenue Reduction & 30 & 21 & 30 & 5 & 22 & 22 & 17 & 21 & 6 \\
\hline & Worry about added work & 36 & 42 & 35 & 1 & 48 & 21 & 13 & 28 & 5 \\
\hline & Distrust epidemic & 14 & 81 & 85 & 5 & 3 & 54 & 40 & 40 & 3 \\
\hline & Column average & 33 & 54 & 57 & 19 & 37 & 37 & 39 & & \\
\hline & Priority & 6 & 2 & 1 & 7 & 5 & 4 & 3 & & \\
\hline & Totally average & \multicolumn{7}{|c|}{40} & & \\
\hline
\end{tabular}

Figure 3. Table of statistical results.

would be also beneficial to arrange short-time and on-site seminars about leadership for project managers and supervisors.

\section{REFERENCES}

[1] Sun Microsystems, "Best-Practice Recommendations for Change Management,” Sun Services White Paper, 2007. http://issuu.com/publishgold/docs/changemgmt_wp_4.08, pp.1

[2] T. Creasey, "Defining Change Management," 2007. http://www.change-management.com/prosci-defining-cja nge-management.pdf, pp.3

[3] R. N. Lussier and C. F. Achua, "Leadership-Theory, Application, \& Skill Development,” South-Western College Pub., Cincinnati, 2006. 


\section{Appendix: Questionnaire}

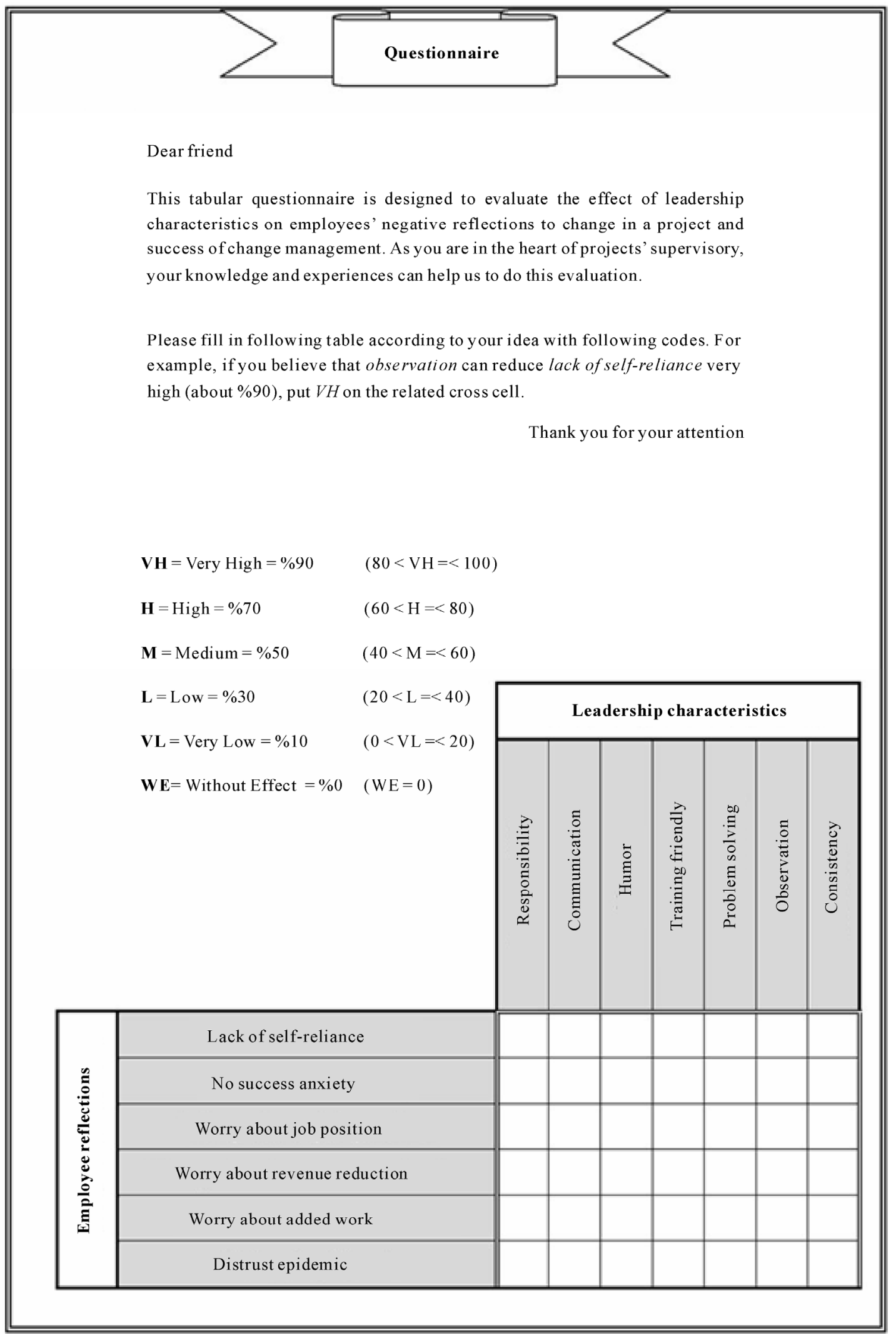

